\section{Utredning av amyloidose}

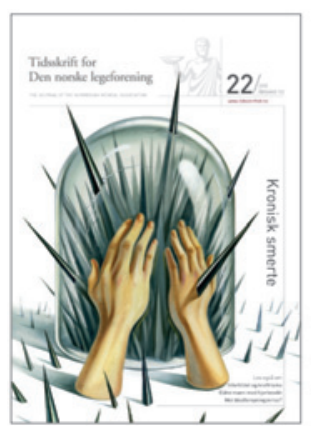

Vi takker for en flott kasuistikk i Tidsskriftet nr. 22/2012 om amyloidose (1), en underdiagnostisert sykdomsgruppe (2). Vi har siden 2010 arbeidet for bedring av amyloidosetyping i Norge, og vi ønsker derfor både å kommentere kasusistikken og komme med noen generelle kommentarer om diagnostikk av amyloidose.

Det ble ikke tatt biopsi av pasienten. Diagnosen for denne pasienten er etter all sannsynlighet riktig, selv om albuminuri og rask progrediering kan tale imot. Internasjonalt er det $\mathrm{i}$ dag imidlertid enighet om at diagnostisering av systemiske amyloidoser bør gjøres med biopsi $(3,4)$. Grunnen er en erkjennelse av at de arvelige amyloidosene er mye vanligere enn tidligere antatt, og at de ofte har vært feildiagnostisert (5). Førstevalget er biopsi av affisert organ, men fettvevsbiopsi er en meget god erstatning og anbefales der biopsi av affisert organ er praktisk eller medisinsk vanskelig $(3,4,6)$. Å utelukke arvelige amyloidoser på grunn av manglende (anerkjent) familiær opphopning er heller ikke mulig. Senil transthyretinamyloidose er en eksklusjonsdiagnose.

En annen grunn til at biopsi har fått en så sentral plass i diagnostiseringen er at en ny teknologi har gjort det mulig å påvise det patologiske proteinet i så godt som alle pasienter (7) og er nå anerkjent som gullstandarden i diagnostisering av amyloidose $(3,4)$. Denne teknologien, lasermikrodisseksjon med massespektrometri er under etablering ved Oslo universitetssykehus selv om vi ikke ennå har muligheten til å tilby dette som et nasjonalt tilbud. Planen er å kunne gjøre dette i løpet av 2013. Teknikken er mer sensitiv og mer spesifikk enn immunhistokjemiske metoder (7), og har den fordelen at den ikke begrenses av hvilke proteiner man ser etter, som antistoffbaserte metoder gjør.

Til slutt: Vi har nylig startet arbeidet med å lage et nasjonalt handlingsprogram for diagnostisering og behandling av amyloidose. Hvis det er interesserte som ønsker å bidra i dette arbeidet, er det bare å ta kontakt. Spesielt kardiologer og nefrologer vil være aktuelle.

Fredrik Hellem Schjesvold

fredrik.hellem.schjesvold@vestreviken.no

Fredrik Hellem Schjesvold (f. 1975) er spesialist i indremedisin og overlege ved Bærum sykehus og stipendiat ved Oslo universitetssykehus. Ingen oppgitte interessekonflikter.

For Norsk arbeidsgruppe for amyloidose

Lorentz Brinch, Oslo universitetssykehus

Tobias Gedde-Dahl d.y., Oslo universitetssykehus

Gunnar Husby, Universitetet i Oslo

Magnus Trygve Røger, Oslo universitetssykehus

Knut Sletten, Universitetet i Oslo

Gustavo de Souza, Oslo universitetssykehus

Erik Heyerdahl Strøm, Oslo universitetssykehus

Astrid Tutturen, Oslo universitetssykehus

Tale Norbye Wien, Diakonhjemmet sykehus

\section{Litteratur}

1. Langholdt AW, Vegsundvåg J. En eldre mann med hjerteinfarkt. Tidsskr Nor Legeforen 2012; 132: 2503-7

2. Schjesvold F, Sjo M, Tangen J et al. Høydosebehandling med stamcellestøtte ved systemisk AL-amyloidose. Tidsskr Nor Legeforen 2008; 128: 1392-6.

3. Leung N, Nasr SH, Sethi S. How I treat amyloidosis: the importance of accurate diagnosis and amyloid typing. Blood 2012; 120: 3206-13.

4. Rajkumar SV. Multiple myeloma: 2011 update on diagnosis, risk-stratification, and management. Am J Hematol 2011; 86: 57-65.

5. Comenzo RL, Zhou P. Fleisher M et al. Seeking confidence in the diagnosis of systemic AL (Ig light-chain) amyloidosis: patients can have both monoclonal gammopathies and hereditary amyloid proteins. Blood 2006; 107: 3489-91.
6. Brambilla F, Lavatelli F, Di Silvestre D et al. Reliable typing of systemic amyloidoses through proteomic analysis of subcutaneous adipose tissue. Blood 2012; 119: 1844-7.

7. Vrana JA, Gamez JD, Madden BJ et al. Classification of amyloidosis by laser microdissection and mass spectrometry-based proteomic analysis in clinical biopsy specimens. Blood 2009; 114: 4957-9.

Publisert som rask respons på nett 3.1. 2013

\section{Manglende kreditering av bildediagnostikken}

Takk for en interessant kasuistikk i Tidsskriftet nr. 22/2012 med en diagnose som sikkert mange flere kunne være oppmerksom på (1).

Vi reagerer imidlertid på et annet aspekt ved artikkelen. Forfatterne har benyttet både et scintigrafibilde av den aktuelle pasienten og et normalt bilde av en annen pasient. Vi kan ikke se at bildediagnostikere er kreditert for bruken av bildene, og det er heller ikke nevnt ved hvilken avdeling bildene er utført.

Vi mener at dette er et gjennomgående trekk i publiseringen av mange artikler. Man har første-, annen- og tredjeforfattere, men sjelden er bildediagnostikken med annet enn i en bisetning. Dette til tross for at bildediagnostikk har er kritisk og avgjørende rolle i moderne diagnostikk. Man kan vanskelig tenke seg diagnose av prolaps uten MR, responsevaluering av cancer uten CT og PET eller diagnostikk av sarkomer uten røntgen og MR/CT. Radiologer og nukleærmedisinere er ikke fotografer bortgjemt i en krok, men verdifulle bidragsytere til klinisk diagnose.

Hvorfor er det blitt slik? Vi tror at innføringen av digitale bildelagringssystemer (PACS) gjør det ekstremt enkelt å «låne» bilder når man trenger det. Men dette er ikke $\mathrm{OK}$ uten videre. Hvert bilde som ligger i PACS representerer lang overveielse og vurdering av teknikk og sekvenser. Beskrivelsen er et produkt av lange og grundige overveielser for å finne akkurat de ord som skal beskrive tilstanden slik at henviser «ser» tilstanden for sitt indre øye.

Problemstillingen er tidligere tatt opp i Tidsskriftet (2). Vi har tidligere publisert en artikkel i Norsk Radiologisk Forenings tidsskrift NORAForum (3) hvor akkurat det samme spørsmålet er tatt opp. Vi hadde håpet at vi skulle slippe å minne Tidsskriftet om akkurat dette.

Men det ser ut som om det er nødvendig også her. Beklageligvis.

\section{Bjørn Løndalen}

bjornlon@getmail.no

Ayca M. Løndalen

Bjørn Løndalen (f. 1969) er radiolog ved Unilabs Røntgen Oslo. Ingen oppgitte interessekonflikter.

Ayca M. Løndalen (f. 1962) er spesialist i nukleærmedisin og overlege ved Seksjon for nukleærmedisin ved Oslo universitetssykehus, Radiumhospitalet.

Ingen oppgitte interessekonflikter.

Litteratur

1. Langsholdt AW, Vegsundvåg J. En eldre mann med hjertesvikt. Tidsskr Nor Legeforen 2012; 132: 2503-7.

2. Stiris MG. Utelatelse av radiologer som medforfattere av artikler. Tidsskr Nor Lægeforen 2003; 123: 1399.

3. Løndalen B, Løndalen AM. Hvem eier røntgebildene? NORAForum 2012; nr. 2: 16.

Publisert som rask respons på nett 28.11. 2012 